\title{
IS CHINA ONLY ASSEMBLING PARTS AND COMPONENTS? THE RECENT SPURT IN HIGH TECH INDUSTRY*
}

\author{
Marcelo José Braga Nonnenberg ${ }^{a}$ \\ Allan Mesentier ${ }^{b}$
}

\begin{abstract}
The purpose of this paper is to evaluate to which degree China is climbing up the technology ladder and increasing its domestic content in high tech industry. More specifically, we will assess whether China has increased its share in world trade of high tech goods and, at the same time, increased its domestic content, changing its role from a mere final assembler to a producer of more intense technology goods. We have built an indicator of domestic value added calculated as the difference between exports of final goods and imports of its parts and components. The main conclusion is that this measure has increased significantly since the early 1990ís, putting in evidence the profound changes that occurred in Chinaís high tech exports in the last two decades
\end{abstract}

KEYWORDS: External trade; innovation; China; production fragmentation.

JEL CLASSIFICATION: F14; O33.

\footnotetext{
* Artigo recebido em 04/05/2012 e aprovado em 06/08/2012.

${ }^{\text {a }}$ Doutor em Economia pela Universidade Federal do Rio de Janeiro (UFRJ) e técnico de planejamento e pesquisa do Instituto de Pesquisa Econômica Aplicada (IPEA). Contato: marcelo.nonnenberg@ipea.gov.br.

${ }^{\mathrm{b}}$ Economista e estudante do mestrado em Economia do Instituto de Economia da UFRJ. Contato: allanmesentier@gmail.com.
} 


\section{A CHINA É APENAS UMA MONTADORA DE PARTES E COMPONENTES? O CRESCIMENTO RECENTE DA INDÚSTRIA DE ALTA TECNOLOGIA}

RESUMO: O objetivo deste artigo é avaliar até que ponto a China vem evoluindo ao longo da cadeia tecnológica e aumentando o conteúdo doméstico de sua indústria de alta tecnologia. Especificamente, será avaliado se a China aumentou sua participação no comércio mundial de bens relativamente intensivos em tecnologia e, ao mesmo tempo, elevou seu conteúdo doméstico, transformando seu papel de mero montador de bens finais para o de produtor de bens mais intensivos em tecnologia. Foi construído um indicador de valor doméstico agregado calculado como a diferença entre as exportações de bens finais e as importações de partes e componentes. A conclusão principal é que esse indicador elevou-se significativamente desde o início da década de 1990, pondo em evidência as profundas modificações operadas nas exportações chinesas nas duas últimas décadas.

PALAVRAS-CHAVE: Comércio exterior; inovação; China; fragmentação da produção. 


\section{INTRODUCTION}

Despite its fantastic economic growth in the last three decades, especially in the manufacturing industry, China is sometimes considered as just a final assembler in the more technology intensive goods, thanks to its low labor cost. According to this view, value added at home in these industries is still very low and the domestic innovation content still weak, compared to other Asian countries, like South Korea or Taiwan.

Does it really matter to be only a final assembler? Many people still believe that innovation must be an in-house process, with key components developed and built in an integrated process. And developing countries, although incorporated in the manufacturing process of a wide range of high tech goods, are not yet responsible for the innovation process or for the production of core parts and components. Srholec (2007), using data for 111 countries and for electronic goods, finds that developing economies attract some "fragments of global production networks in electronics, while technology intensive activities remain concentrated elsewhere" (op.cit., p. 218).

But this picture has evolved in the last years. Product and process development and manufacturing are spread into many countries and firms. Within this new global corporate network, what really matters is to control some core competences. Which can be in designing, logistics, retail networks etc.

Nevertheless, within national boundaries, it is important that domestic firms evolve through the technology ladder in order to capture the benefits of innovation. In this case, a firm that only makes final assembling of parts and components is hardly seen as a good candidate for capturing these benefits. So, at the end of the day, product and process innovation remain a key factor to achieve a fast and sustainable economic growth.

No one disputes the fact that Chinese labor cost is still very low by international standards and this has been one of the main determinants of economic growth in China in the last 35 years. But is China recent growth in manufacturing still so dependent on low cost labor or has China made a significant effort in innovation in the last years that allowed her to watch a progressive advance in domestic production of technology intensive goods, increasing domestic value added?

Our goal here is to evaluate to which degree China is climbing up the technology ladder and increasing its domestic content in high tech industry. More specifically, we will assess whether China has increased its share in world trade of high tech goods and, at the same time, increased its domestic content, changing its role from a mere final assembler to a producer of more intense technology goods. We must also stress that our purpose is not to determine the reasons behind this process. This analysis will be based on foreign trade data provided by the World Bank database World Integrated 
Trade Solution (WITS) via COMTRADE at five-digit ${ }^{1}$ level of Standard International Trade Classification (SITC), rev. $3^{2}$.

This paper is organized as follows. Section 2 presents a theoretical background for the internationalization and outsourcing of production. The methodological aspects and source of data are examined in section 3. The recent development of trade in high tech goods, with a special emphasis on Asian trade, is examined in section 4, while section 5 examines some important features of Chinese trade. Section 6 presents the main contribution of this paper, namely the analysis of the evolution of domestic value added of high tech goods in China.

\section{THEORETICAL ASPECTS}

Part of the recent literature on international trade and foreign direct investment sheds some light in the process of why China is increasing its domestic value added in high tech goods. On one side, we have the theory of fragmentation and, on the other, the theory of Global Production Networks (GPN).

The point of departure for these two theoretical strands is the fact that manufacturing production is even more spread between international borders and firm boundaries. Production of such disparate goods as garments, shoes, automobiles and TV sets is increasingly split in several countries and several firms, not necessarily close to each other. And this internationalization of production leads to increasing trade in parts and components worldwide, from manufactures of small components to final assemblers. This new feature requires new theoretical background.

In the last 30 years, the acknowledgement of monopolistic competition and increasing returns brought a new light to the theory of international trade. This theory emerged after the empirical work by Grubel and Lloyd (1975) about the importance of intraindustry trade and has been developed in papers like Helpman (1981) and Krugman (1980, 1979). Comparative advantage was not dead yet but contributed to the analysis of a decreasing share of global trade, based on relative factor endowments while the new geography theory explained the growing intra-industry trade.

But in recent years, a new phenomenon arose looking for new explanations. Production of manufactured goods is been increasingly outsourced, with parts and components produced by developing economies. This tendency developed within multi-

\footnotetext{
${ }^{1}$ In some cases, the four digit level was enough.

${ }^{2}$ We have chosen SITC. Revision 3 instead of other possible classifications, like Harmonized System in order to stick to United Nations Conference on Trade and Development (UNCTAD) classification of goods by technology intensity presented in Table 1 below.
} 
ple value-chains, from garments to shoes to electronics and unfolded in the theory of fragmentation of production (Jones et al., 2004; Jones and Kierzkowski, 2004a, 2004b; and Bonham et al., 2007).

Initially, fragmentation of production was the responsibility of multinational corporations (MNCs) thanks to scale of operations and the need to master the necessary knowledge (Helleiner, 1981). In some industries, like automobiles, this remains true. Big corporations prefer to concentrate manufacturing of some parts and components in some countries and final assembling in others. And production remains, for the most part, being made within firm boundaries and not outsourced to other firms and leads to intra-firm trade.

But in a growing number of industries, production of parts and components and even final assembling is been outsourced to other firms, located mainly in Asia and, in second place, in Eastern Europe. This is happening in a large number of goods but is especially relevant in electronics.

What constitutes the main differences of the "new geography theory" of increasing returns/monopolistic competition and fragmentation theory? According to Jones and Kierzkowski (2004a) it can be summarized as follows: First, consider two separate possibilities of production locations and production costs. One, IF (integrated firm) is when all production takes place in a single location. The other, OF (outsourced fragments), is when production takes place in more than one location (outsourced). It is assumed by convenience that production costs in OF are always lower than in IF because in separate locations "factor prices or factor productivities are for each fragment more suited to factor proportions in that fragment. Regions in which labor is relatively inexpensive are used for the more labor-intensive fragment" (Jones and Kierzkowski, 2004, p. 7).

Costs of production in IF must then be compared to costs in OF added to costs of transportation, communication and knowledge transfer (service links). The crucial aspect is which activity exhibits increasing returns to scale. In the first case, increasing returns happen in production blocks, at the same time that service links have constant returns to scale. It is shown that in this case, after a certain level of production, costs in IF are lower than in OF plus service links. So, increasing returns in production lead to agglomeration of production.

In the second case, production costs are constant to scale while service links exhibit increasing returns. In this case, after a certain level of production, OF-plus costs are lower than IF, leading to fragmentation of production. Summarizing, depending on where happen increasing returns, production is integrated in one location, thanks to economies of scale or is fragmented in several locations, across the border, thanks to differences in relative factor prices in different countries.

Why fragmentation of production became more prevalent in the last years? The answer lies, of course, in what happened to service links. This is not to say that increasing 
returns vanished from manufacturing production but that the reduction in these other costs has more than compensated them. Four factors have played a major role in this aspect (Jones et al., 2004; Bonham et al., 2007). First, comes separability or modularity of production stages. In most value chains, components may be used interchangeably in different production process, mainly in electronics.

Second, there is evidence of falling transports costs which benefits trade in parts and components and also finished goods, making it cheaper to split production worldwide. Third, barriers to trade have declined substantially during the last decades. According to data by TRAINS/UNCTAD (World Bank, 2010), tariffs from high income countries for manufactured goods (classes 5-8) fell from a range of 3.9\% $-8.5 \%$ in 1989 to a range of $1.6 \% 4.6 \%$ in 2010 . Considering low and middle income countries, the fall is even more pronounced - from a range of $22.7 \% 33.3 \%$ in 1989 to $5.3 \%$ $11.5 \%$ in 2010 .

Finally, the reduction in communication costs, due to progress on internet and telecommunications in general, made it much easier and speedier to coordinate and monitor activities in separate locations.

The other literature refers to Global Production Networks (GPN). In the last 50 years a lot has been written about internationalization of production and MNCs. It is a well established fact that MNCs set production facilities in different locations for a variety of reasons ${ }^{3}$. But, until recently, production was essentially organized within firm boundaries. The novelty is that, in the last years, it is also organized trough markets. i.e. made by different firms. So each firm is responsible to one or several production phases. We may say that fragmentation of production refers to the fact that production is a multi-country process, and GPN refers to it being a multi-firm process. This form of governance has received other names, more or less interchangeable, like global commodity chains or global value chains (Gereffi, 1999, 1994; Gereffi et al., 2005) and also Global Flagship Networks (GFN) (Ernst 2005a, 2005b).

But what drives the creation of this network? Gereffi et al. (2005) state that transaction cost economics explains why global production is organized within firm boundaries or trough markets. They try to build a theory of value chain governance based on three factors. The first is complexity of information and knowledge transfer, specially of product and process specifications. The second is the degree to which this information and knowledge may be codified and thus transmitted to partners. And finally, the capability of actual and potential suppliers to understand and adopt the required knowledge. If these three factors are classified as high or low, eight possible combinations are allowed, from

\footnotetext{
${ }^{3}$ See Dunning $(1998,1993)$ for instance.
} 
which the authors retain only five possible types of governance, namely: markets, modular value chains, relational value chains, captive value chains and hierarchies. From markets to hierarchies, the degree of coordination and power asymmetry increases.

Ernst and Kim (2001), on the other hand, consider that the main drivers of GPN formation are institutional change trough liberalization, information technology and competition. By the first factor, they mean liberalization of trade, capital flows, FDI policies and privatization. As for the second, is the "rapid development and diffusion of information and communication technology". And the third refers to the fact that firms must now be competitive in major markets and in different countries, changing the determinants of firm organization and location. "No firm, not even a dominant market leader, can generate all the different capabilities internally that are necessary to cope with the requirements of global competition. Competitive success thus critically depends on a capacity to selectively source specialized capabilities outside the firm..." (op.cit., p. 6)

GPNs are organized as follows. At the top of the value chain, there is a flagship company, also called vendor, that detains some core competencies and proprietary assets in key areas. This firm coordinates and controls, in varying degrees, the whole production process. In most cases (but not all), the flagship company is responsible for the generation of knowledge and, in some cases and in varying degrees, for product development. Development (in some degree) and manufacturing are the tasks of local suppliers. Some authors make a division between higher tier suppliers and lower tier suppliers (Ernst 2005a; Ernst and Kim, 2001).

Higher tier suppliers have also capabilities in areas like designing review, prototype building, pilot production and mass manufacturing. In many cases, they are also responsible for $\mathrm{R} \& \mathrm{D}$ and product development. Lower tier suppliers generally do not have proprietary assets and their advantage lies in low cost and speed of production, with tiny profit margins.

Hobday (1995) puts the development of GPN in historical perspective, especially in Asian countries, introducing the idea of latecomer firms, which are exactly the local suppliers. As defined by him, latecomer firm "faces two sets of competitive disadvantages in attempting to compete in export markets. The first is technological in character. [Ö] The second disadvantage concerns leading-edge markets and demanding users. [Ö] (T)he latecomer firm is dislocated from the mainstream international markets it wishes to supply" (op.cit., p. 1172).

GPNs are alternatively known by other names. Hobday $(2000,1995)$ utilizes the expression Original Equipment Manufacture (OEM) and Own Design and Manufacture (ODM). The first designates systems where the latecomer is involved on mass production, sometimes participating in the selection of capital equipment. The second system 
refers to situations when the subcontractor is also responsible for product design but the brand remains a proprietary asset of the vendor.

Ernst (2005a) distinguishes between Contract Manufacturer (CM) and OEM. In this view, OEM "derives their market powers from selling global brands, regardless of whether design and production is done in-house or outsourced" (page 104). CM is the firm responsible mainly for mass production and supply chain services.

To make things more complicated, Dedrick et al. (2007) state that CM is an old name for small firms providing basically assembly services while ODM is a Taiwanese name for a CM that also offers product engineering. OEM is an expression to be avoided because it has been used to designate global flagships (in car industry) but also CM in Taiwan. So, we consider that, to avoid all this confusion, we will refer only to flagship and supplier, when talking about GPNs.

\section{METHODOLOGICAL ASPECTS}

As stated before, our goal here is to evaluate to which degree China is climbing up the technology ladder and increasing the domestic content of her high tech exports. The hypothesis is that many firms in developed countries, including Taiwan and South Korea, are increasingly outsourcing manufacturing and product development of high tech goods to China and, as a consequence, she is increasing innovation efforts leading to a greater production of parts and components for these goods.

Ideally, it would be necessary to obtain a direct measure of domestic value added in high tech production industry. However, an input-output matrix would be needed at a very disaggregated level. The problem is that this matrix is not available and it would be very difficult to build it for a country with poor statistics like China.

In this paper, it has been adopted an alternative approach. Domestic value added is the sum of incomes generated in the production process. Alternatively, it is the difference between production value and intermediate consumption. In the case of high tech industry, it is reasonable to imagine that the bulk of this consumption consists of other high tech goods. Based on Brazilian intermediate consumption table for 2006, in the case of electronic goods, consumption of electronics was $46 \%$ of total intermediate consumption in this activity (43\% for 2000). Therefore, the difference between industry production value and intermediate consumption of goods produced by the same industry would be a sound proxy of the variation of its value added. By analogy, the difference between exports and imports of its parts and components would also be a fair proxy for the evolution of its domestic value added. It must be well understood that this difference may be used to reflect the evolution of the domestic value added, not its level. The latter is also the result of domestic production and exports of parts 
and components, domestic sales and imports of final goods, not to mention imports and domestic production of the remaining inputs.

An important caveat refers to domestic market growth. Suppose that the export value of a particular good remains stable for some years and the share of imported parts and components is kept constant. At the same time, domestic sales of that good increase by a significant amount, causing imported inputs to grow. In this case, as export value is constant while import value of inputs grows, our measure for domestic value added will decrease.

It must be noticed that this methodology is in line with the recent WTO Made in the World Initiative launched in 2010, that points to the importance of measuring trade using value added (WTO and IDE-JETRO, 2011).

All data comes from WITS (World Bank, 2010) at Standard International Trade Classification, rev. $3^{4}$ at 5 digit level and the period under analysis is 1992-2009. At this level of disaggregation, export and import data is broken down between final goods and parts thereof - only goods classified in divisions 75, 76, 77, 79, 87 and 88. As mentioned above, it does not comprehend parts and other inputs classified in other divisions. For instance, section 75 stands for Office machines and automatic data-processing machines. It is divided between 751 - Office machines, 752 - Automatic data-processing machines and units thereof; magnetic or optical readers, machines for transcribing data onto data media in coded form and machines for processing such data, n.e.s. and 759 - Parts and accessories (other than covers, carrying cases and the like) suitable for use solely or principally with machines falling within groups 751 and 752. We have labeled 751+752 as final goods and 759 as inputs. Sometimes data at 4 digit level is all we need, but sometimes it is necessary to go to the 5 digit level.

Based on this methodology, it has not been possible to include every product at 4 or 5 digit level. In some cases, some goods were included as final goods and others as their parts and components. But in other cases, this distinction was not possible, even at five-digit level of SITC 3. (data at SITC rev. 4 is more disaggregated, but the series is much shorter). Some goods may be classified as parts and components for many different other products, like diodes, transistors and similar semiconductor devices (7763). In other cases, like instruments and appliances for medical, surgical, dental or veterinary purposes (872), it was not possible to detect appropriate parts and components. In the great majority of cases, especially in more recent years, at least $75 \%$ of categories included as high tech goods could be classified by means of this procedure. We call each set of final goods/parts and components a pair.

\footnotetext{
${ }^{4}$ Heretofore simply SITC3.
} 
Additionally, we have utilized a classification of goods by technological intensity developed by UNCTAD plus a minor modification, which is the disaggregation of section E on E1 and E2 as presented in Table 1. In this paper, we shall analyze exclusively goods classified as E2 or high tech goods. In Annex 1 we present all goods at 3-digit level, according to SITC rev.3.

Table 1 - Goods by technology intensity

\begin{tabular}{l}
\hline A - Primary goods \\
\hline B - Manufactured goods intensive in labor or natural resources \\
\hline C - Manufactured goods with low technology intensity \\
\hline D - Manufactured goods with medium technology intensity \\
\hline E1 - Manufactured goods with high technology intensity - chemicals \\
\hline E2 - Manufactured goods with high technology intensity - electronics, aircraft and precision instruments \\
\hline F - Goods not classified elsewhere \\
\hline G1 - Goods not analyzed for insufficiency of data \\
\hline G2 - Fuels
\end{tabular}

Source: Author's elaboration based on UNCTAD (2002).

\section{RECENT CHANGES IN HIGH TECH TRADE}

To put Chinese trade flows in high tech goods in perspective, we will analyze the main changes in bilateral world trade. International trade in high tech goods increased dramatically in the last twenty years. From world exports of about US\$ 393 billion in 1990, they have reached US\$ 1,510 billion in 2009 (see Figure 1). But

Figure 1 - World exports of high tech goods for selected countries and groups of countries (in US\$ million)

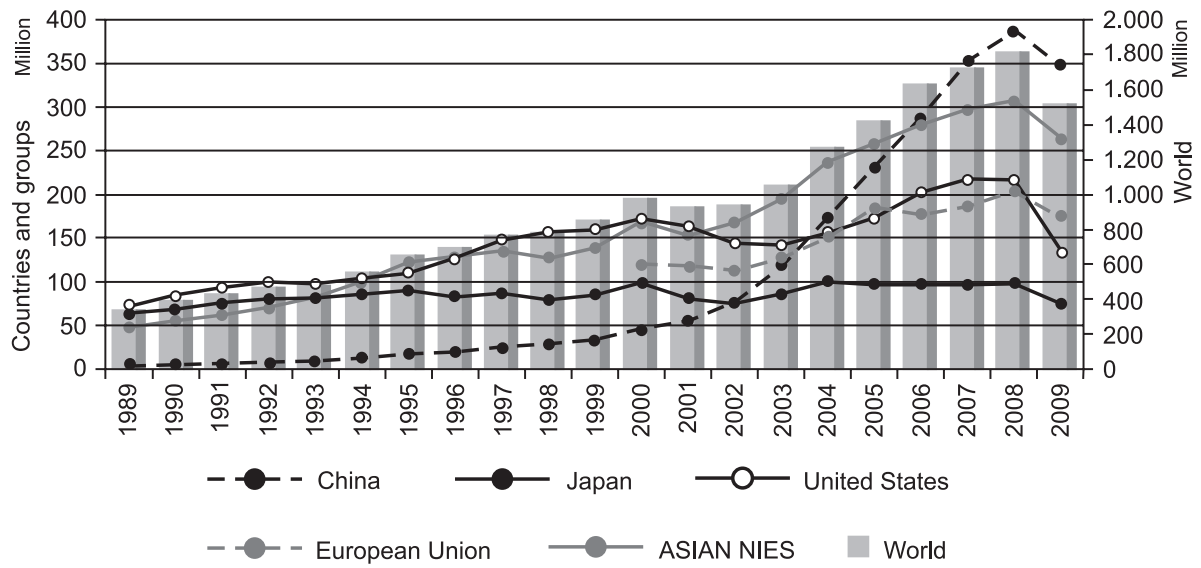

Source: World Bank (2010). 
more impressive are the changes in its structure. As may be seen from Tables 1 and 2, non-Asian countries (especially United States and European Union) have seen their share decrease from $65 \%$ in 1990 to $49 \%$ in 2009, while Japan watched its exports share decline from $18 \%$ to $5 \%$. At the same time, developing Asia countries ${ }^{5}$ increased their overall exports ten-fold, from US\$ 68,6 billion to US\$ 689,9 billion in 2009, augmenting their share from $18 \%$ in 1990 to $46 \%$ in 2009 . But this figure wouldnít be the same without China exports climbing from US\$ 4,3 billion to US\$ 347 billion at the same time.

These changes reflect, in large degree, the increase in intra-Asian trade in these goods. From 1990 to 2009, exports from ASEAN, Asian NIEs and China to these same countries jumped from US\$ 18 billion to US\$ 285 billion, or from 5\% to 19\% of global flows. And the change in East Asian trade is basically the result of the rise of Global Production Networks in high-tech industries. This movement started with developed countries like Japan, European Union and United States off-shoring production to the NIEs countries. But in the last twenty years, global companies outsourced increasing shares of their production (including more technology intensive production processes) to developing Asian countries, thanks to the existence of relatively high-skilled workers with low reduction of trade and investment barriers and a decrease of transport costs.

Beginning in the nineties, countries like Hong Kong and Taiwan transferred parts of their value chain to mainland China, mostly final assembly processes, intensive in non-skilled labor. For some years, multinational corporations (especially from Asian countries) exported parts and components to China only to be assembled and re-exported to final consumers.

This reorganization of the global production process was responsible to a significant part of international trade flows in high tech goods in the last 20 years.

As a consequence, developing Asia except China, exports to non-Asian countries increased slightly in relative terms during the nineties only to reduce their share in the next nine years. At the same time, Japanese exports decreased even in absolute numbers. Chinese exports, on the contrary, plummeted during all these years, but especially after 2000. From almost zero in 1990, China reached 37\% of Japanese imports and 19\% of Other countries imports in 2009. Also remarkable is the increase in China-NIEs trade. While NIEs exports to China jumped from US\$ 3,6 billion in 1990 to US\$ 94,4 billion in 2009, Chinese exports to the NIEs climbed from US\$3,7 billion to US\$107.3 billion. In other words, the bulk of the increase in China imports during these years came from

\footnotetext{
${ }^{5}$ Countries belonging to the Association of South-East Asian Nations (ASEAN) and the Newly Industrialized Nations and China (Asian NIEs).
} 
NIEs, in first place, followed by Other (basically developed countries) and Japan. Meanwhile, almost one third of Chinaís exports growth was directed to the NIEs.

Mostly, China-NIEs trade reflects flows to and from Hong Kong and mainland China, that can be explained in large part by the fact that Hong Kong is today more a commercial than a manufacturing location. But a growing share of these bilateral flows is also the result of trade between China and Taiwan. And as will be explained in more detail in the next section, China is increasing its share in the manufacturing of intermediate goods in high tech goods. In other words, China is less and less a mere final assembler of high tech goods on its final stages of production, to become a producer of its parts and accessories, bringing as a consequence an increase in its domestic value added. This process could only be the result of large efforts in innovation and labor qualification.

In the present paper, as already explained, high tech goods means electronics, aircraft, precision instruments and photographic and optical goods. From China point of view, the most relevant ones are office and data processing machines and its parts and telecommunication and sound recording and reproducing equipment (which includes TV receivers and telephone sets).

So, the remainder of this section will focus on trade flows in these two value chains. Letís start with office and data processing machines. In terms of SITC3, these goods represent chapter 75 (Office machines and automatic data-processing machines) split into 751 (Office machines), 752 (Automatic data-processing machines and units thereof; magnetic or optical readers, machines for transcribing data onto data media and machines for processing such data, n.e.s.) and 759 (Parts and accessories suitable for use solely or principally with machines falling within groups 751 and 752). The first two sections are final goods and the last one, their main inputs.

Trade flows in both groups of goods increased substantially from 1990 to 2009.751 +752 ("computers", for short) exports jumped from US\$ 81.4 billion in 1990 to US\$ 301.7 billion in 2009, as can be seen from Tables 3 and 4 . It is easy to see that the share from developed countries dropped dramatically from $80 \%$ to $39 \%$ during this period. At the same time, exports from NIEs increased from 1990 to 2000 only to drop in the last decade, while flows from ASEAN countries also experienced a huge increase. This increase in intra-regional trade in IT goods was already analyzed by Bonham et al. (2007). But what happened to China exports is astonishing. From almost zero in 1990, its exports were propelled to US\$ 125 billion in 2009 , or $42 \%$ of total external sales of these products.

It is interesting to examine what happened to global sales of main inputs for "computer" final goods, classified in section 759. From 1990 to 2000, its total exports increased 232\%, to reach US\$ 165 billion. During this period, Chinese exports jumped 


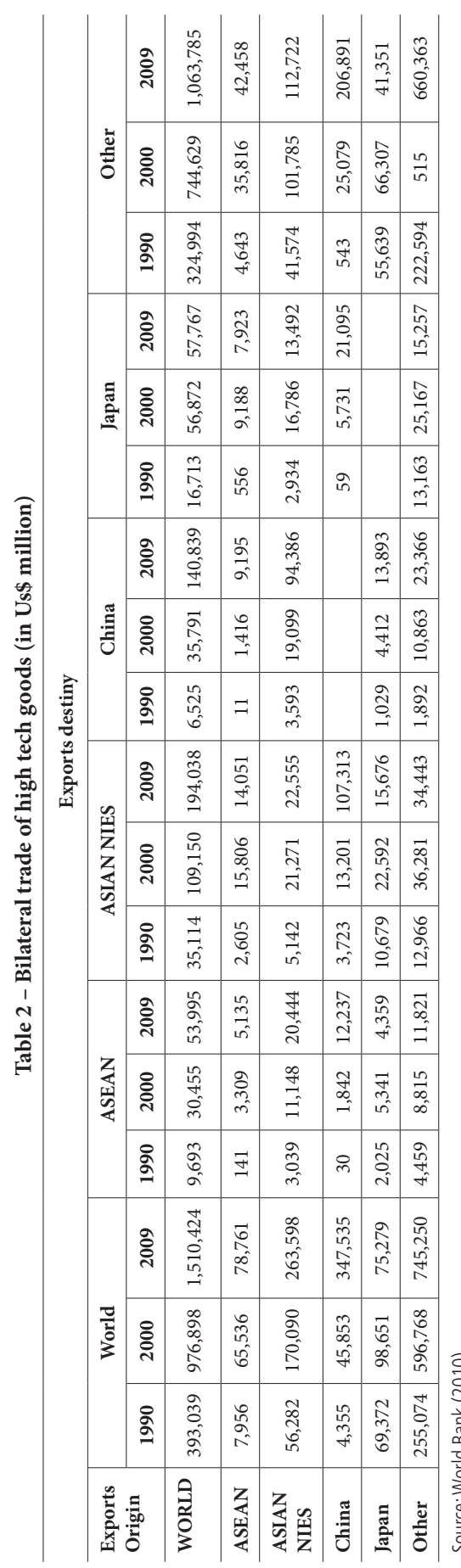

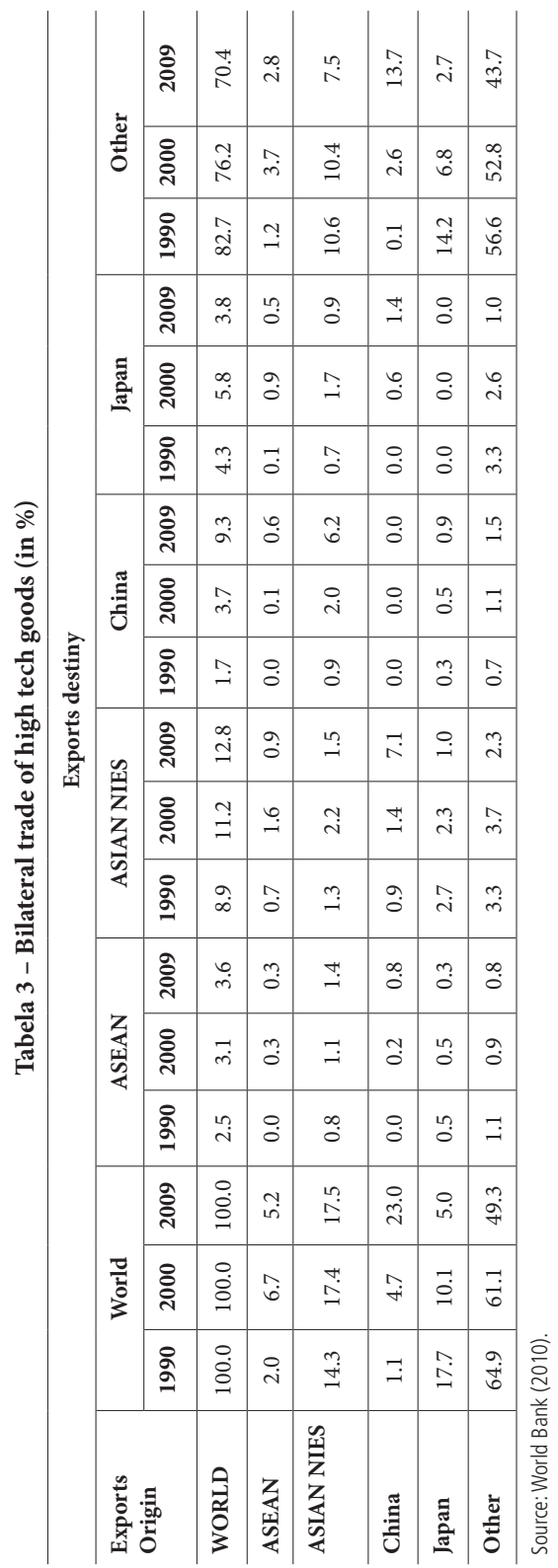


from a very small figure to US\$ 6 billion, or 3.7\% of total trade. But in the next 9 years, its exports jumped to US\$32 billion, or a share of 18\%, the double as the figure for ASEAN countries. During these years, exports from all other countries, except ASIAN NIEs, decreased in absolute figures. And $40 \%$ of Chinaís exports went to ASIAN NIEs and $45 \%$ to Other countries. This means that China gained competitiveness not only in final goods, which are more intensive in low wage labor in its final production phases, but also in parts and components, that require much more specialized labor for its manufacturing. This gain came as companies from other Asian countries, especially Taiwan, expanded its plants in mainland China.

Another interesting aspect is the increasing complementarity between China and Asian NIEs in high tech trade. Both in computers and its parts and components, bilateral flows between these countries increased by a substantial amount. For instance, in heading 759 exports from Asian NIEs to China jumped from US\$ 346 million in 1990 to US\$ 19458 million in 2009. At the same time, exports from China to these countries increased from only US\$ 90 million to astonishing US\$ 12380 million. These figures suggest that not only is China importing intermediate goods to final assembling but is also assuming an important role in the supply chain for data processing machines industry in Asia, providing parts and components to countries like South Korea and Taiwan. As will be seen in the next paragraphs, more or less the same picture emerges in telecom goods.

Turning now to Radio \& TV receivers and parts, analysis is based on final goods (761 - Television receivers including video monitors and video projectors, 762 - Radio-broadcast receivers and 76432 - mobile phones) and its parts (7761 - Television picture tubes, cathode-ray , 7762 - Other electronic valves and tubes - including television camera tubes - and 764.93 - Parts and accessories suitable for use solely or principally with the apparatus of division 76: with the apparatus and equipment of groups 761 and 762 and subgroups 764.3 and 764.8) $)^{6}$. Although telephone sets are classified elsewhere, in heading 764.11, mobile phones must be analyzed together with Radio and TV receivers because parts of both groups are included under heading 764.93 and cannot be further disaggregated.

As can be seen from Tables 7, 8, 9 and 10, global exports of final goods rose fivefold from 1992 to 2009 , to reach US $\$ 216.6$ billion, while sales of its parts jumped from US\$ 25 billion to US\$ 44.8 billion in the same period. It is remarkable that $40 \%$ of the increase of final goods exports came from the Rest of the World. This increase derives in great part from exports of TV receivers from Eastern Europe (Hungary, Czech Republic, Slovakia and Poland) and Mexico. At the same time, exports from Japan plummeted

\footnotetext{
${ }^{6}$ Even at-5 digit level, the classification is not split enougt to avoid counting of parts that do not belong to this group. Data must be seen only as a proxy for effective flows.
} 


\begin{tabular}{|c|c|c|c|c|c|c|c|}
\hline \multirow{3}{*}{ 离 } & ఫે & $\begin{array}{l}\text { o } \\
\text {. } \\
\text { הీ }\end{array}$ & $\stackrel{\circ}{\stackrel{5}{=}}$ & $\begin{array}{l}\stackrel{+}{~} \\
\text { ले }\end{array}$ & $\begin{array}{l}\stackrel{\partial}{\overrightarrow{2}} \\
\infty \\
\infty\end{array}$ & $\begin{array}{l}\infty \\
\infty \\
\infty \\
\infty \\
\infty\end{array}$ & \begin{tabular}{c}
8 \\
0 \\
0 \\
0 \\
\hdashline \\
0
\end{tabular} \\
\hline & ఫે & 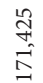 & $\begin{array}{l}\vec{त} \\
\hat{n} \\
\hat{=}\end{array}$ & $\begin{array}{l}\text { సे } \\
\text { ले } \\
\text { స్ }\end{array}$ & $\begin{array}{l}\infty \\
\infty \\
0 \\
\infty\end{array}$ & $\begin{array}{l}2 \\
8 \\
0 \\
1\end{array}$ & 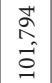 \\
\hline & よ & 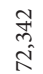 & 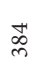 & $\begin{array}{l}\underset{\tilde{N}}{\tilde{m}} \\
\vec{n}\end{array}$ & f & \begin{tabular}{l} 
స్ \\
\multirow{-}{*}{}
\end{tabular} & $\begin{array}{l}8 \\
b \\
10 \\
f \\
f\end{array}$ \\
\hline \multirow[b]{3}{*}{ 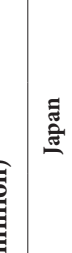 } & ڤ્તે & ڤે & $\begin{array}{l}\hat{\sigma} \\
\hat{i}\end{array}$ & 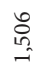 & 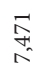 & ' & 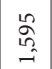 \\
\hline & ఫ్రి & 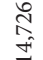 & $\frac{\infty}{\vec{m}}$ & $\begin{array}{l}\infty \\
\stackrel{2}{\aleph} \\
\hat{\sigma}\end{array}$ & 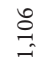 & ' & $\begin{array}{c}3 \\
4 \\
10 \\
\rightarrow+1\end{array}$ \\
\hline & ڤ & $\begin{array}{l}a \\
\infty \\
0 \\
0\end{array}$ & in & $\stackrel{\infty}{\mathfrak{q}}$ & 0 & ' & $\begin{array}{c}+ \\
0 \\
0 \\
\sim\end{array}$ \\
\hline \multirow{3}{*}{ 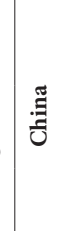 } & ذ્તે & ָิ & 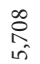 & $\begin{array}{l}\text { 우 } \\
\text { مू }\end{array}$ & ' & 员 & $\underset{\underset{\sim}{2}}{\stackrel{2}{2}}$ \\
\hline & ठั่ & $\overrightarrow{\mathbb{N}}$ & 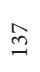 & $\begin{array}{l}\text { \& } \\
\text { i }\end{array}$ & ' & $\stackrel{2}{2}$ & $\stackrel{\hat{2}}{\vec{\imath}}$ \\
\hline & ఏి & $\vec{F}$ & - & ક્సે & ' & 88 & in \\
\hline \multirow{3}{*}{$\mid \begin{array}{l}\mathbf{y} \\
\mathbf{Z} \\
\mathbf{Z} \\
\mathbf{z} \\
\mathbf{z}\end{array}$} & ڤેेે & $\begin{array}{l}2 \\
\text { in } \\
\text { D. } \\
\text { - }\end{array}$ & $\begin{array}{l}\text { 岕 } \\
\text { ले }\end{array}$ & $\begin{array}{l}\underset{i}{*} \\
\hat{i}\end{array}$ & 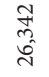 & $\frac{1}{6}$ & $\begin{array}{c}\hat{a} \\
\hat{m} \\
\overbrace{}^{2}\end{array}$ \\
\hline & ¿̊̀ & $\begin{array}{l}\infty \\
\stackrel{\infty}{\alpha} \\
\Omega \\
\Omega\end{array}$ & $\stackrel{\vec{m}}{m}$ & $\begin{array}{l}\infty \\
\stackrel{\infty}{10}\end{array}$ & $\begin{array}{l}\vec{F} \\
\text { i }\end{array}$ & 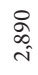 & \begin{tabular}{|}
$\hat{\widehat{J}}$ \\
$\hat{i n}$
\end{tabular} \\
\hline & よ & $\begin{array}{l}0 \\
8 \\
\text { in }\end{array}$ & $\widetilde{\Xi}$ & $\hat{\vec{o}}$ & $\vec{\sim}$ & . & 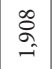 \\
\hline \multirow{3}{*}{ 站 } & ठ્ণે & 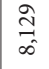 & $\underset{\rightarrow}{\vec{F}}$ & $\begin{array}{c}\stackrel{0}{0} \\
i \\
i\end{array}$ & $\begin{array}{l}\vec{n} \\
\vec{m}\end{array}$ & a & $\begin{array}{l}+ \\
\infty \\
\infty\end{array}$ \\
\hline & ¿ें & ते & $\triangleq$ & $\underset{-}{\stackrel{f}{f}}$ & $\exists$ & สี & 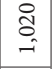 \\
\hline & ఏి & ஃ & - & $\begin{array}{l}\stackrel{n}{n} \\
\end{array}$ & 0 & $\stackrel{\infty}{-}$ & 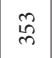 \\
\hline \multirow{3}{*}{$\begin{array}{l}\bar{\pi} \\
3 \\
3\end{array}$} & ఫ્సે & 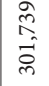 & $\begin{array}{l}\text { H } \\
\text { ळे } \\
\text { के }\end{array}$ & 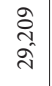 & 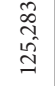 & $\begin{array}{l}\infty \\
\infty \\
1 \\
\hat{n}\end{array}$ & $\begin{array}{l}\stackrel{P}{A} \\
\vec{\exists} \\
\exists\end{array}$ \\
\hline & ¿̊̀ & 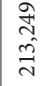 & 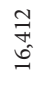 & $\begin{array}{l}\infty \\
\stackrel{+}{+} \\
\vec{n}\end{array}$ & $\begin{array}{l}\mathbb{J} \\
\text { in } \\
\stackrel{I}{I}\end{array}$ & 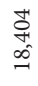 & $\mid \begin{array}{c}\vec{s} \\
\stackrel{+}{+} \\
\stackrel{+}{\exists}\end{array}$ \\
\hline & ฉ & 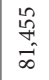 & 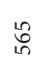 & $\begin{array}{l}8 \\
\stackrel{1}{1} \\
\text { in }\end{array}$ & $\stackrel{\infty}{n}$ & $\begin{array}{l}\vec{\Xi} \\
\stackrel{0}{0}\end{array}$ & $\mid \begin{array}{c}\vec{r} \\
\hat{2} \\
\hat{q}^{2}\end{array}$ \\
\hline \multicolumn{2}{|c|}{ 嗬 } & \begin{tabular}{l}
$\overrightarrow{7}$ \\
\multirow{2}{*}{} \\
3 \\
3
\end{tabular} & 焉 & 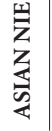 & 苞 & 芯 & 节 \\
\hline
\end{tabular}

\begin{tabular}{|c|c|c|c|c|c|c|c|}
\hline \multirow{3}{*}{ to } & ठ্ণે & 옷 & $\hat{i n}$ & $\stackrel{+}{+}$ & חें & $\stackrel{m}{-}$ & $\stackrel{m}{\tilde{m}}$ \\
\hline & ષ્ণે & $\underset{\infty}{\stackrel{\infty}{0}}$ & $\dot{+}$ & $\mid \begin{array}{l}\dot{0} \\
-\end{array}$ & $\vec{F}$ & $\vec{n}$ & $\stackrel{\curvearrowright}{ғ}$ \\
\hline & & & & & & & \\
\hline \multirow{3}{*}{ 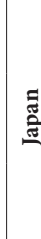 } & ठ্ণ & $\stackrel{+H}{+}$ & $\hat{o}$ & $\stackrel{n}{0}$ & $\stackrel{n}{i}$ & ' & $\stackrel{12}{0}$ \\
\hline & ఫ్రి & $\hat{b}$ & $\exists$ & $\stackrel{\sim}{m}$ & $\stackrel{n}{0}$ & ' & $\overrightarrow{\mathrm{i}}$ \\
\hline & ఏి & $\stackrel{i n}{m}$ & $\overrightarrow{0}$ & 吕 & $\because$ & ' & $\vec{i}$ \\
\hline \multirow{3}{*}{ ].ّ } & ठ્તે & $\stackrel{\infty}{i}$ & $\stackrel{9}{-}$ & $\tilde{m}$ & ' & ơ & $\stackrel{0}{0}$ \\
\hline & ષ્సి & $\stackrel{\circ}{i}$ & $\overrightarrow{0}$ & $\stackrel{m}{-}$ & ' & $\overrightarrow{0}$ & $\stackrel{\bullet}{0}$ \\
\hline & ஃ & $\stackrel{\text { L }}{0}$ & $\ddot{0}$ & $\stackrel{m}{0}$ & ' & $\overrightarrow{0}$ & ֶ̊ \\
\hline \multirow{3}{*}{$\begin{array}{l}\frac{1}{2} \\
z \\
\frac{1}{3} \\
\frac{3}{4}\end{array}$} & ठ્సે & $\overrightarrow{\mathrm{I}}$ & $\stackrel{m}{\rightarrow}$ & $\hat{0}$ & $\stackrel{\infty}{\infty}$ & ơ & 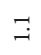 \\
\hline & ¿̊ి. & $\ddot{\sigma}$ & 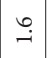 & $\stackrel{\vec{i}}{\mathrm{i}}$ & $\stackrel{1}{\rightarrow}$ & $\stackrel{\sharp}{\leftrightarrows}$ & $\begin{array}{l}\infty \\
i\end{array}$ \\
\hline & Дू & $\overrightarrow{6}$ & $\overrightarrow{0}$ & $\stackrel{m}{-}$ & $\stackrel{m}{0}$ & $\vec{i}$ & $\stackrel{m}{i}$ \\
\hline \multirow{3}{*}{$\frac{2}{4}$} & ठ্ণి & $\hat{i}$ & $\begin{array}{l}n \\
0\end{array}$ & $\hat{o}$ & $\stackrel{\leftrightarrow}{-}$ & $\ddot{0}$ & $\stackrel{?}{0}$ \\
\hline & ठ্ণે & $\stackrel{\leftrightarrow}{-}$ & $\overrightarrow{0}$ & $\hat{o}$ & $\overrightarrow{0}$ & $\overrightarrow{0}$ & $\begin{array}{l}n \\
0\end{array}$ \\
\hline & ুু & $\stackrel{\circ}{\rightarrow}$ & $\stackrel{0}{0}$ & $\stackrel{m}{0}$ & $\stackrel{0}{0}$ & $\tilde{o}$ & $\begin{array}{l}\ddot{0} \\
0\end{array}$ \\
\hline \multirow{3}{*}{$\begin{array}{l}0 \\
\overline{3} \\
3\end{array}$} & ठे̀ે & $\dot{8}$ & $\stackrel{n}{\circ}$ & $\hat{\sigma}$ & $\frac{n}{7}$ & $\cong$ & $\begin{array}{l}\infty \\
\dot{m} \\
\dot{m}\end{array}$ \\
\hline & ठั่ & $\dot{0}$ & 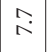 & $\vec{i}$ & in & $\begin{array}{l}0 \\
\infty \\
\infty\end{array}$ & $\stackrel{\grave{n}}{i}$ \\
\hline & よ̊ & $\dot{8}$ & $\hat{o}$ & $\begin{array}{l}\hat{\infty} \\
\infty\end{array}$ & $\stackrel{m}{0}$ & $\hat{\Omega}$ & $\begin{array}{l}0 \\
\dot{8}\end{array}$ \\
\hline \multicolumn{2}{|c|}{ 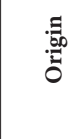 } & 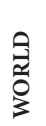 & $\begin{array}{l}\mathrm{Z} \\
\text { 営 } \\
\frac{2}{4}\end{array}$ & 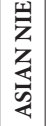 & 苞 & 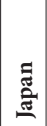 & 节 \\
\hline
\end{tabular}




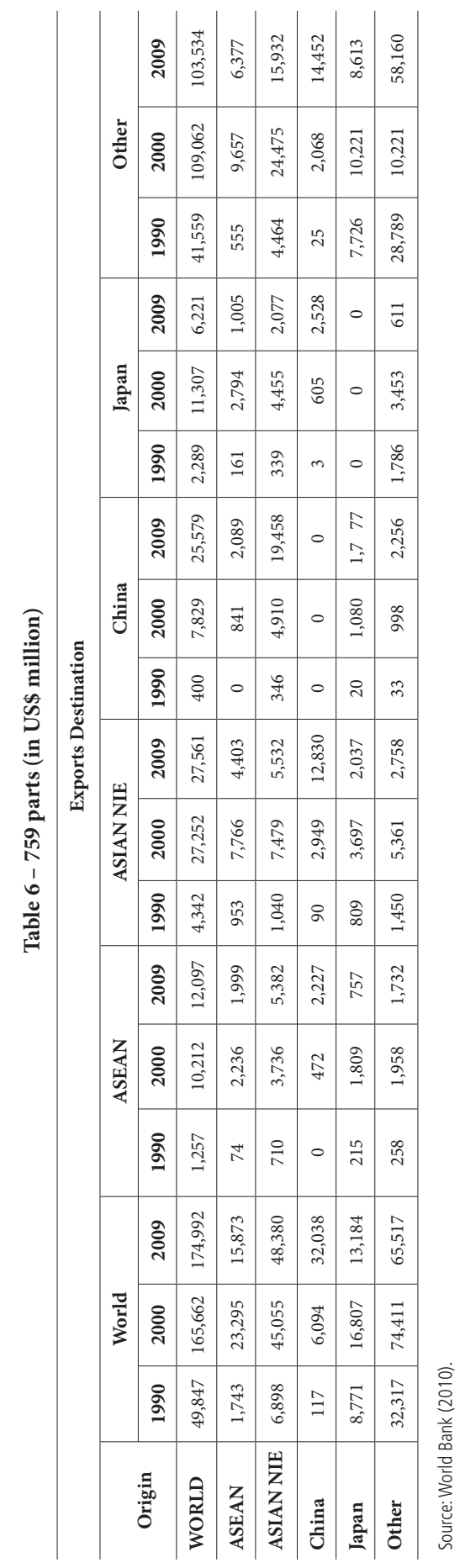

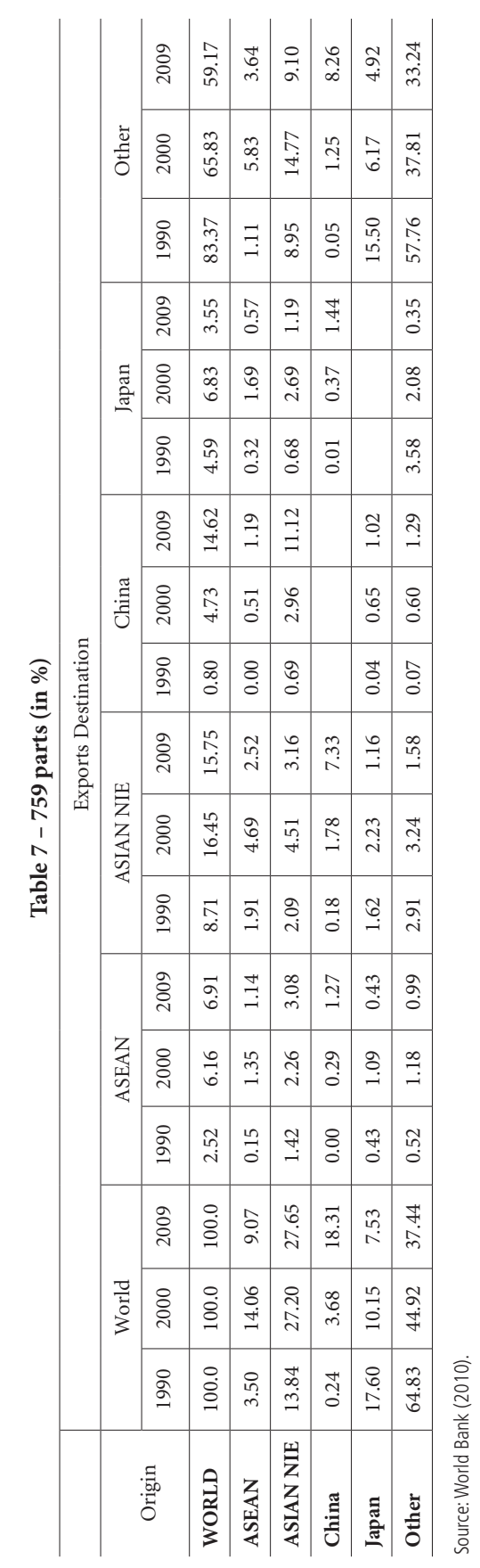




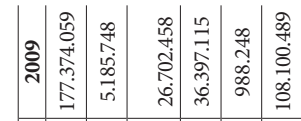

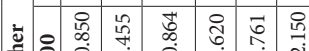

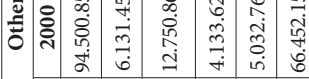

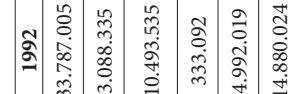

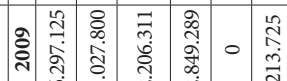

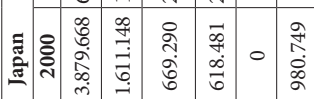

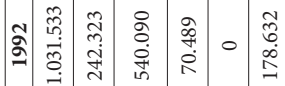

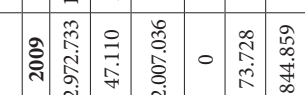

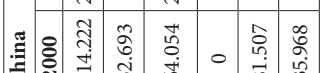

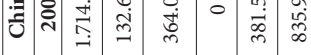

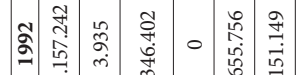

苦

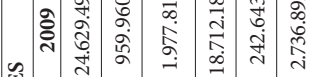

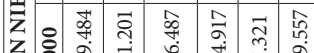

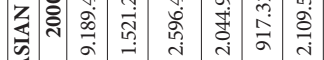

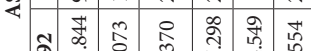

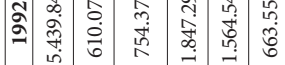

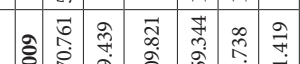

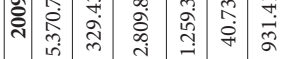

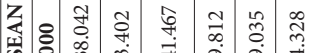

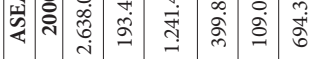

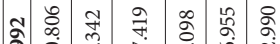

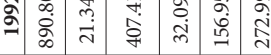

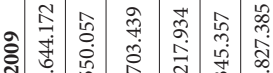

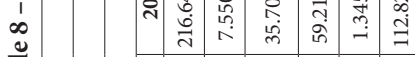

च

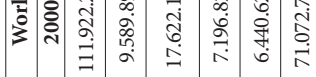

ป สิ

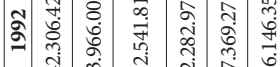

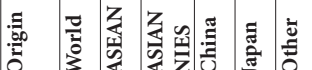

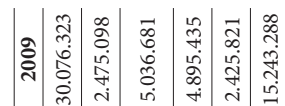

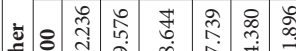

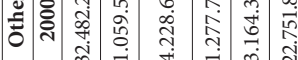

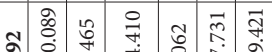

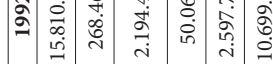

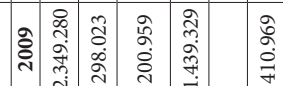

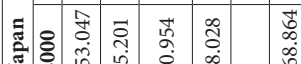

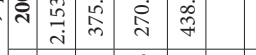

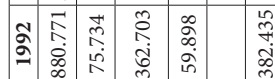

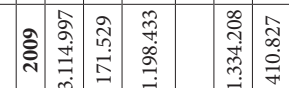

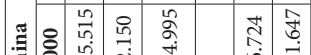

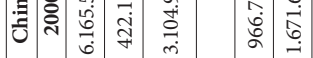

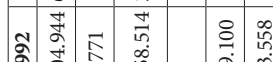

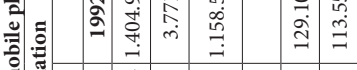

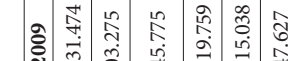

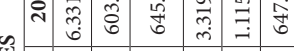

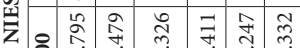

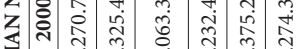
का 준

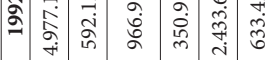

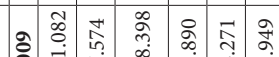

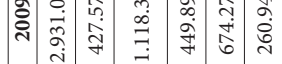

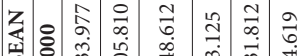

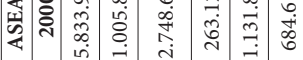
ㅇำ울

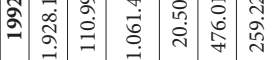

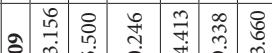

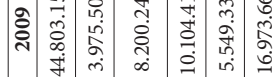

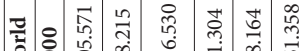

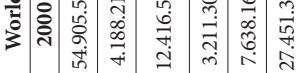

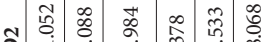

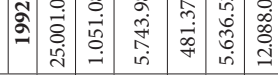

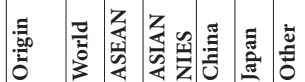

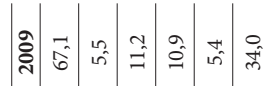

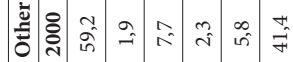

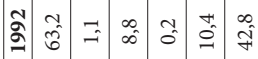

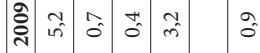

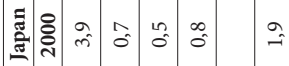

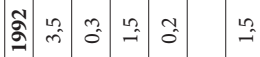

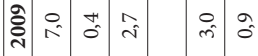

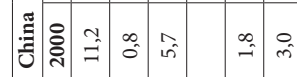

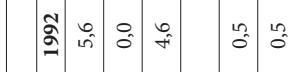

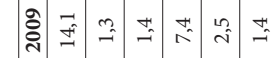

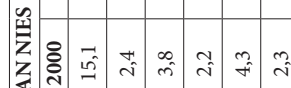
政

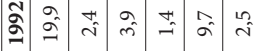

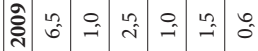

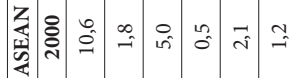

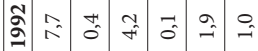

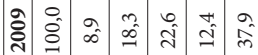

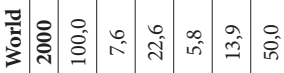

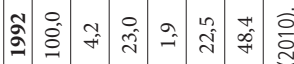

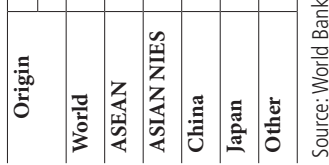


while ASEAN sales almost doubled. But the most striking feature is the performance of Chinese exports that reached US\$ 59.2 billion, or $27 \%$ of total exports in 2009 . This makes China the biggest TV and radio receivers and mobile phones exporter, with roughly $2 / 3$ of its sales going to the Rest of the World (ROW).

Total exports of parts and accessories increased during the nineties to decrease in the following years. Sales from the ROW reached US\$27.5 billion in 2000 only to fall to US\$ 17 billion in 2009. Exports of parts and accessories are increasingly made in Asian countries. While ASEAN countries were responsible for $9 \%$ of total exports, China accounts for $23 \%$, an equivalent share of final goods market. And it is also worth noting that most of its sales are directed to developed countries - NIEs, Japan and ROW ${ }^{7}$.

\section{CHANGES IN CHINESE EXPORTS BY TECHNOLOGY INTENSITY}

Until very recently, China was a low value added goods exporter, as may be seen from Figure 2. Considering only the categories from A to E2, in $198586 \%$ of its exports consisted of goods of categories A and B, i.e., commodities and products intensive in natural resources or labor; this figure decreased to $56 \%$ in 1997, still a substantial amount. But in 2009 , only $32 \%$ of its exports consisted of these goods, while the share of electronics and precision instruments, which was close to zero in the early eighties, jumped to $27 \%$.

The bulk of this increase came from computers and telecom goods, where lies Chinese comparative advantages. Most importantly, Chinese increasing advantages in these goods correspond to the decreasing advantages of developed countries in these same sectors. Figure 3 depicts the trade balance of high tech goods, for China and high income countries, split by main categories. As can be seen, especially in computers, the increase in trade balance in China equals the decrease in high income countries. Net exports of telecom goods also turned positive and gained momentum after 2007, while the opposite occurred in high income countries since 2004. As for the other main categories of high tech goods, namely aircraft, professional, scientific and controlling instruments and photographic apparatus and equipment and optical goods, China trade balance continued in negative territory.

Only in 2004 high tech goods became the most important export category. Of course, its production is still concentrated in a few goods. But this is not very different from what happened in other Asian countries, like Korea or Japan, where high tech production and exports are also concentrated in a limited amount of goods.

We turn now to the analysis of the domestic value added of the main categories. As mentioned above, data has been prepared at 4 or even 5 digit level,

\footnotetext{
${ }^{7}$ Mostly, ROW market for parts and accessories comprises developed countries and Eastern Europe.
} 
Figure 2 - Chinaís exports by technology intensity (in US\$ billion)

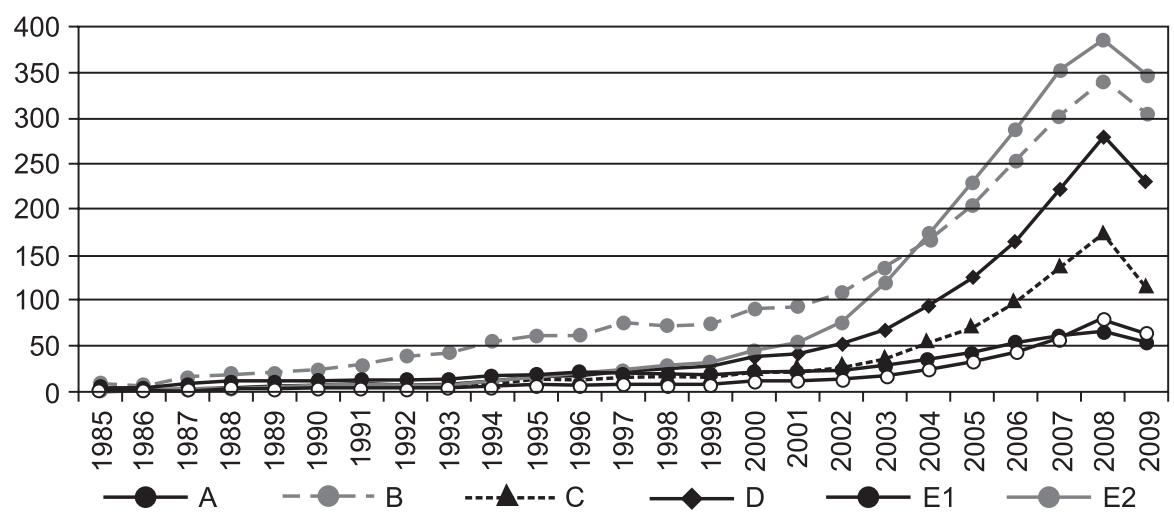

Source: World Bank (2010).

\section{DOMESTIC VALUE ADDED IN FOREIGN TRADE HIGH TECH GOODS}

As already mentioned, the analysis will be based on a proxy for domestic value added, consisting of the difference between exports of final goods and imports of their main parts and components, as identified by COMTRADE data, for goods classified as intensive in high technology (see Annex A). Although this not strictly domestic value added, we will use this terminology for convenience. All data are shown as a $\%$ of exports of the two-digit division.

Starting with division 75 , Office machines and automatic data processing machines, it has been possible to determine five pairs of goods. It is easy to see by Figure 4 that the most important one is automatic data processing machines, computers for short, as its value corresponds to almost all chapter 75. From 1992 to 1995, domestic value added as a $\%$ of division 75 exports reversed its signal from negative to positive, reaching $30 \%$. In 2003, they reached another level, of around 75\%, that remained more or less constant since then. The other four categories are office machines and their share in world trade is small and decreasing, like typewriters and calculating machines.

Chapter 76 includes telecommunications, sound recording and television equipment, with a pattern very similar to division 75 . In this case, we could identify four categories: 761-762-7643 comprises TV and radio receivers (basically flat panel TVs) and mobile phones $^{8}, 763$ sound and TV recorders and reproducers, 7641 - basically telephone sets

\footnotetext{
${ }^{8}$ Mobile phones are not included in subgroup 7641 but in basic heading 764.32 (transmission apparatus incorporating reception apparatus). But it is impossible to separate it from 761-762 because its parts are included in the same heading, 764.93. The alternative thus would be to eliminate these goods which would hinder
} 
Figure 3(a) - High income countries, trade balance, high tech goods (in US\$ billion)

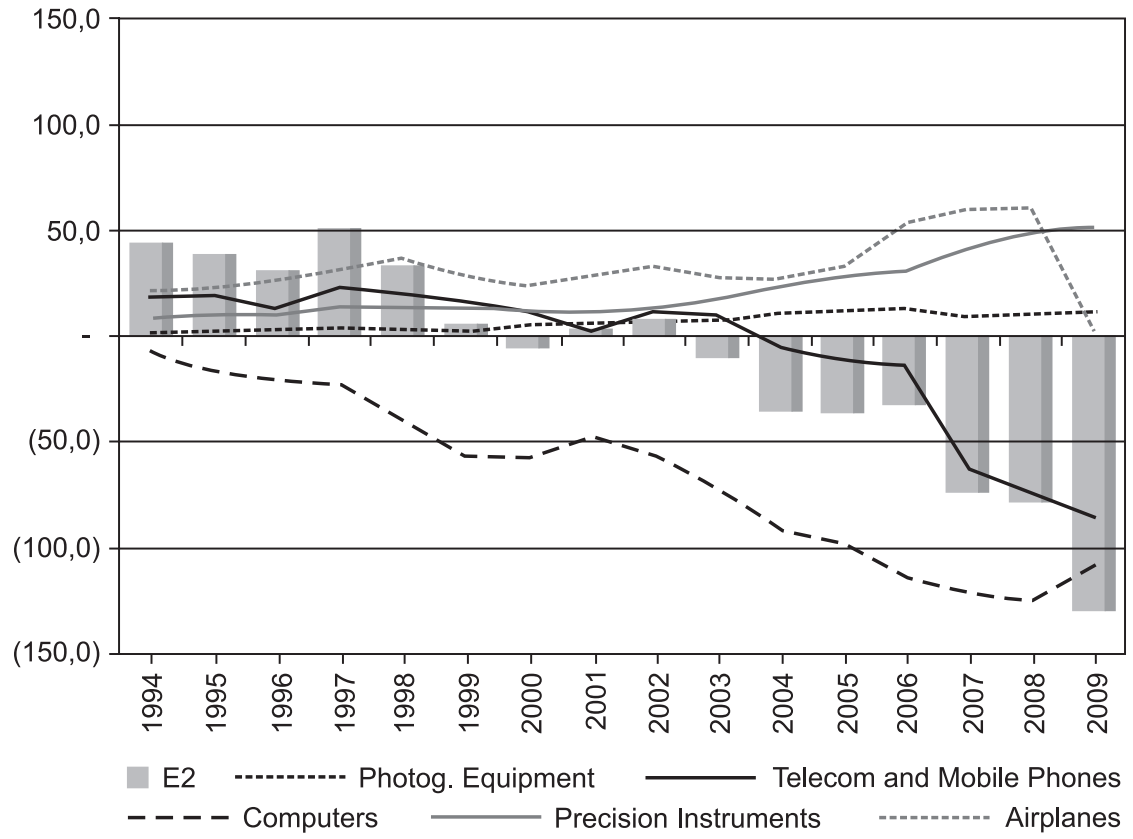

Figure 3(b) - China, trade balance, high tech goods (in US\$ billion)

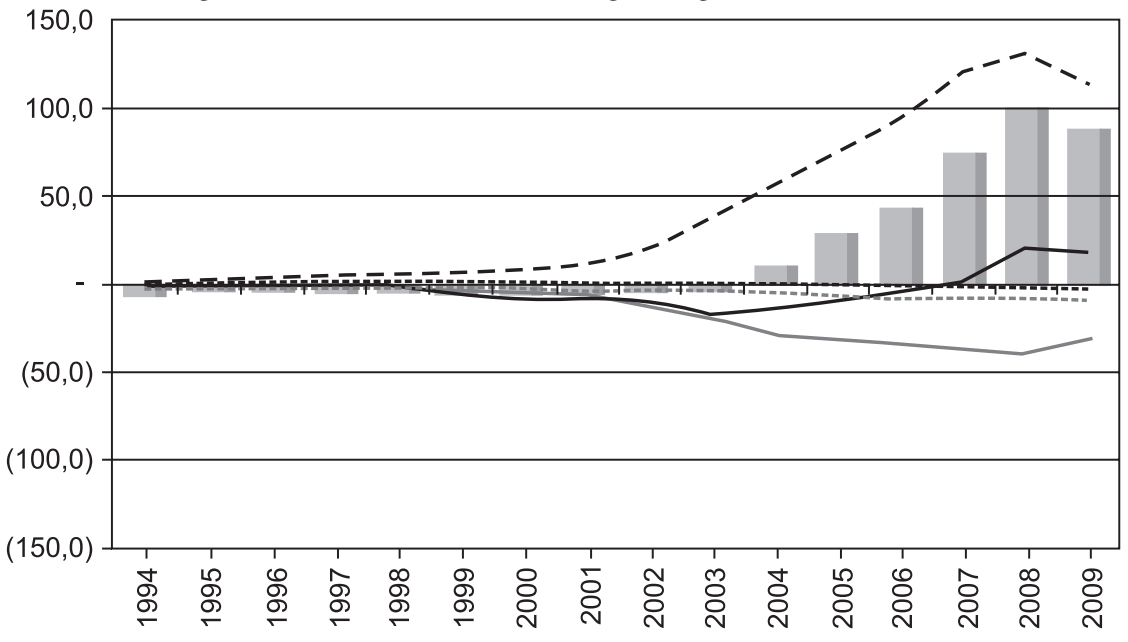

E2

Photog. Equipment

Precision Instruments
Airplanes 
Figure 4 - Domestic value added, division 75, office machines and automatic data-processing machines (as a \% of exports)

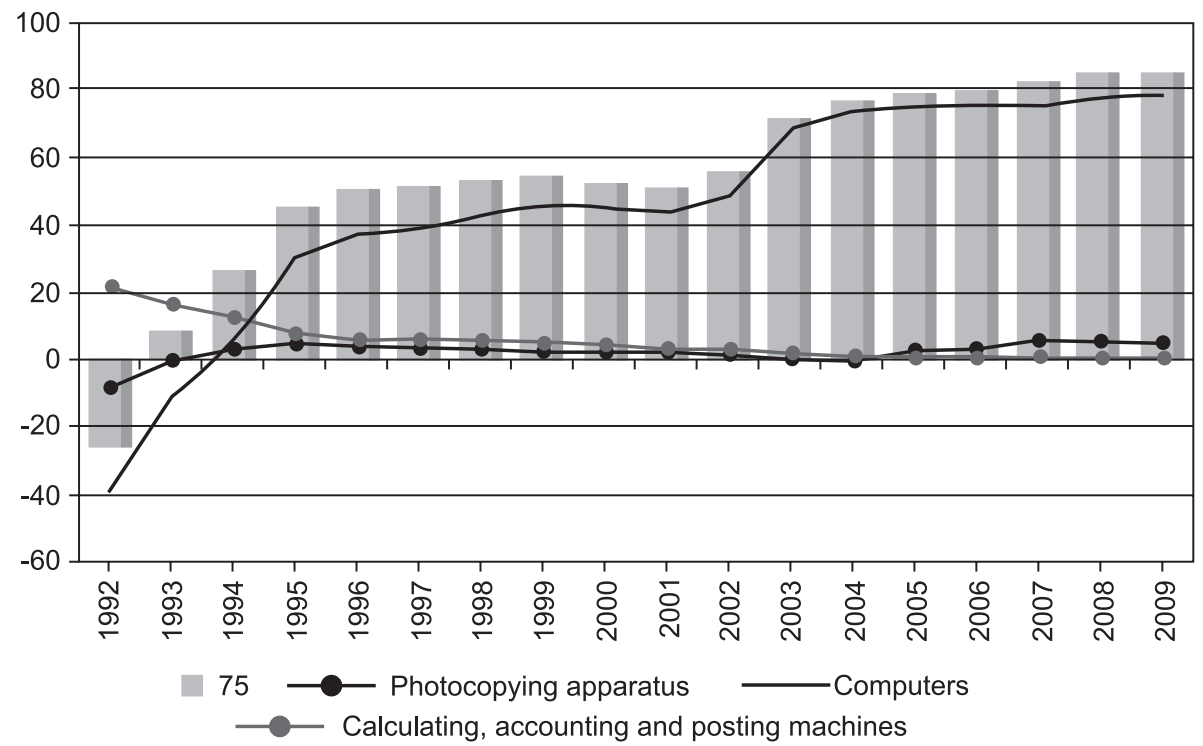

Source: Author's elaboration based on World Bank (2010).

(not including mobile phones, see footnote 9) and 7642 - microphones and loudspeakers. Here, the most important group of goods consists of TVs, radios and mobile phones. Domestic value added declined abruptly between 1992 and 1999. During this period, China's production of mobile phones was near zero. At the same time, imports of parts and components grew at a rapid pace while TVs exports remained almost stagnant. But in 2000 both exports of mobile phones and flat panel TVs started growing at an impressive pace. As a consequence, in 2009, domestic value added reached almost $75 \%$ of group exports. As noted above, China is now the biggest world producer of flat panel TVs. Domestic production of TV sets grew from almost zero in 1978 to 903 million units in 2008. But the surge in production and exports has been accompanied by a strong increase in domestic production of parts and components, especially electronic equipment other than TV tubes. It must also be noted that domestic production of mobile phones increased ten-fold from 2000 to 2008, reaching 560 million units, according to NBS data.

The third group in our analysis is Division 79, aircraft and associated equipment. Clearly, China is not yet a net exporter of aircraft, as can be seen from Figure 6, but is becoming an important producer. The evidence is the strong increase in imports of parts and components for these goods. 
Figure 5 - Domestic value added, division 76, telecommunications and sound-recording and reproducing apparatus and equipment (as a \% of exports)

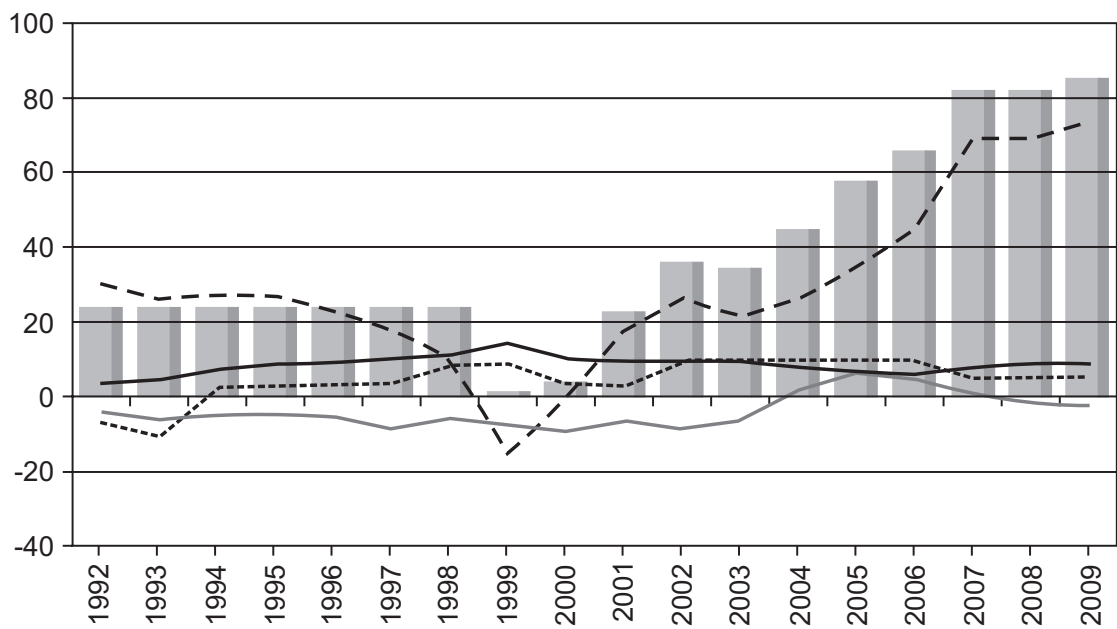

76 - - - - TVs, radios and mobile phones

Microphones \& loudspeakers

Sound and TV recorders \& reprod.

Telephone sets (excl. mobiles)

Source: World Bank (2010)

Figure 6 - Domestic value added, division 79, aircraft and associated equipment (as a $\%$ of exports)

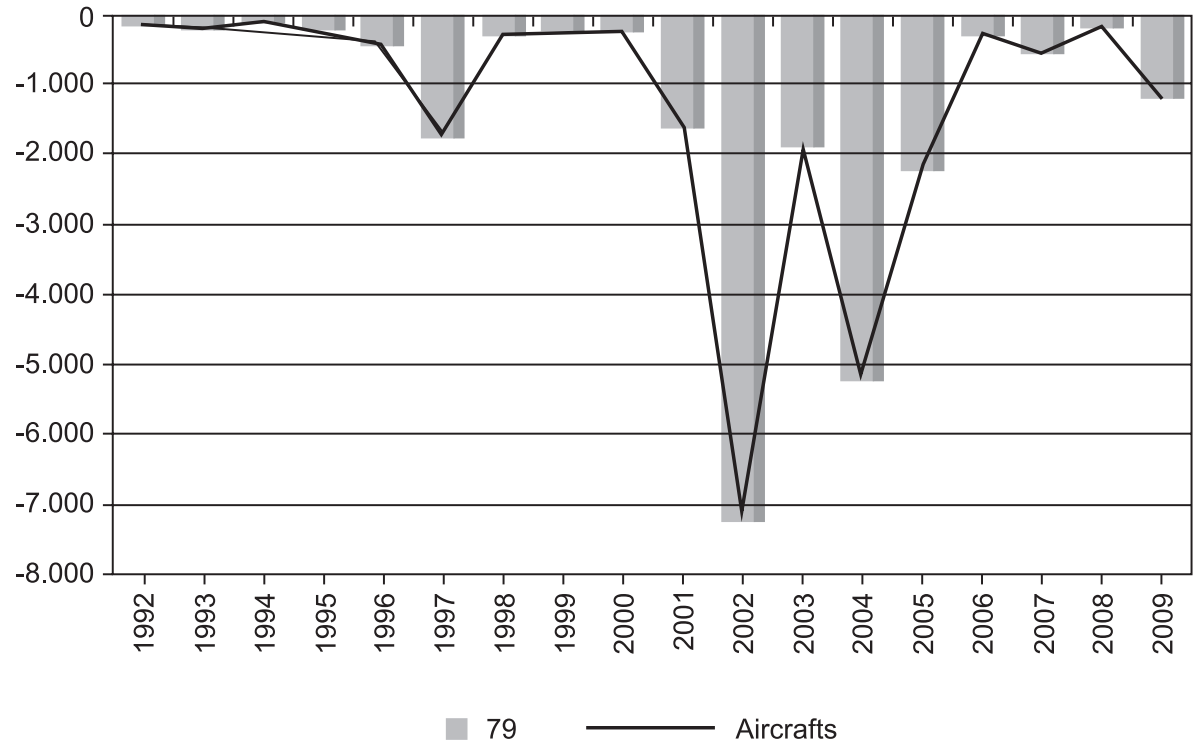

Source: Author's elaboration based on World Bank (2010). 
Division 87 includes all Professional, Scientific and Controlling Instruments. In this case, it has been possible to disaggregate data up to every subgroup, at the 4-digit level. Until 2001, the share of each subgroup was more or less balanced. But the surge of its exports started in 2002, due basically to subgroup 8719, liquid crystal devices, lasers; other optical appliances and instruments. Optical devices industry may have received positive spillovers from the development of flat panel TVs production as there is a clear convergence of technologies in these sectors. As may be seen from Figure 7, the relative weight of LCD, lasers and other optical appliances in total exports of Division 87 jumped from around $10 \%$, in the first years of the series, to nearly $60 \%$ in the last three years, greatly influencing the final result. It must be stressed that this a very highly technology intense industry and produces goods utilized by many other high tech sectors, providing a clear statement of Chinaís growth in technology absorption.

Figure 7 - Domestic value added, division 87, professional, scientific and controlling instruments and apparatus (as a \% of exports)

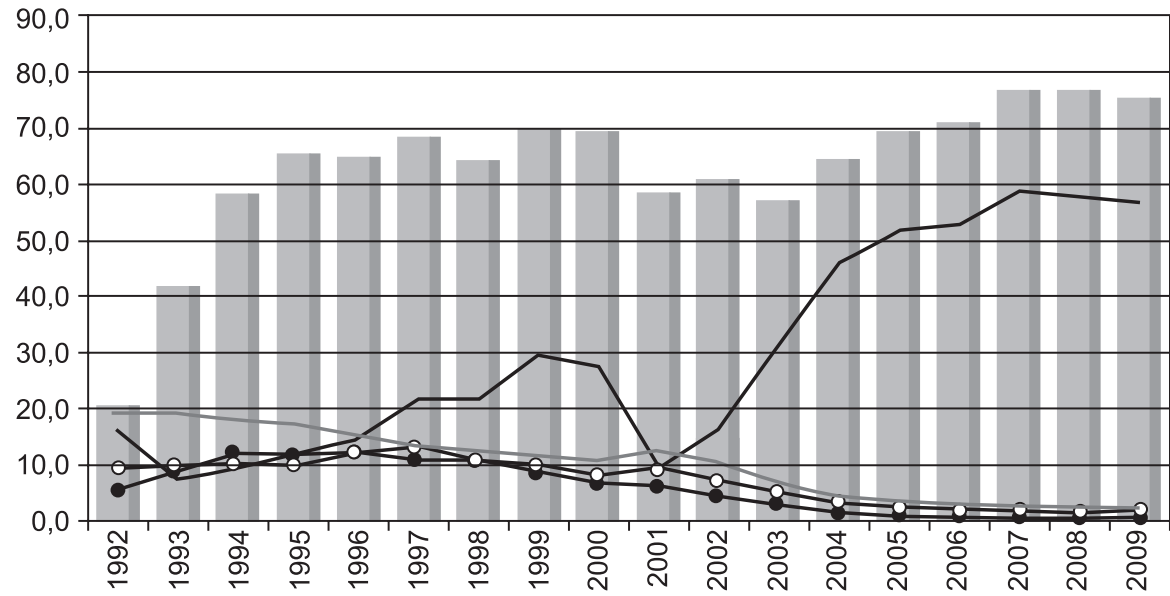

$87 \mathrm{VTI} \longrightarrow$ binoculars and other optical telescopes

Liquid crystal devices, lasers, other optical appliances

- other instruments

Calculating and other instruments

Source: Author's elaboration based on World Bank (2010).

Finally, Division 88 refers to photographic apparatus, equipment and supplies and optical goods, watches and clocks. The most important subgroups therein are 8811-8813 photographic equipment and supplies, 8842 - spectacles and spectacle frames and 885 - watches and clocks. It is worth noting that, in order to include digital photo cameras, 
we had to consider also heading 763.81, although it belongs to Telecommunications Equipment ${ }^{9}$. At the same time, it has not been possible to include all parts and components related to this item which are considered as parts and components for TV and radio receivers. So, any underestimation here is compensated by an overestimation of the same amount in TV and radios. But even if, say, half the value for its parts and components is included as imports, the amount of domestic value added would not change dramatically, especially in the last 4 years. And the increase in DVA for photographic equipment is very strong since 2000. At the same time, the other two items did not show any substantial increase. Our measure of DVA jumped from $25 \%$ of exports in 1992 to more than $90 \%$ in recent years

Figure 8 - Domestic value added, division 88, photographic apparatus, equipment and supplies and optical goods, watches and clocks (as a \% of exports)

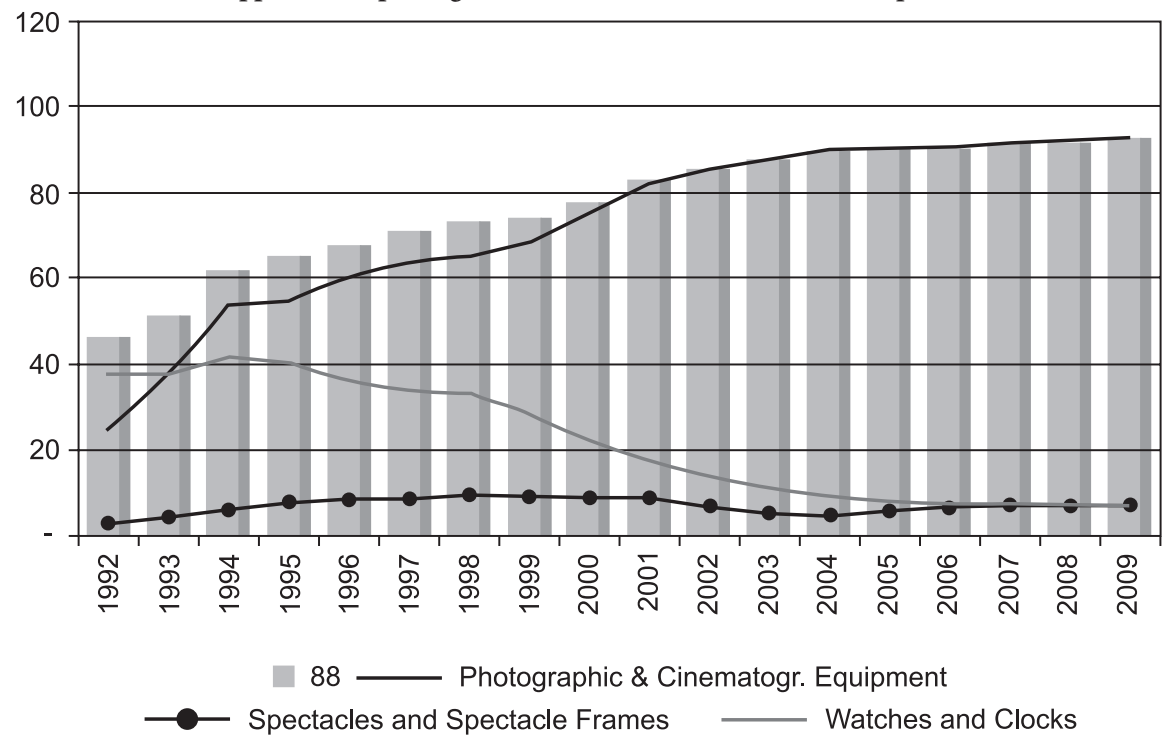

Source: Author's elaboration based on World Bank (2010).

Summing up, there has been a strong increase in domestic value added in some high tech goods produced in China since 2002-2003, basically in automatic data processing machines, TV and radio equipment, including mobile phones, optical instruments (LCD) and photographic and cinematographic equipment. From the products

\footnotetext{
${ }^{9}$ This heading includes TV cameras and video cameras, which is a source of error. But it is a much smaller error than not to include digital cameras in the item for Photographic Equipment.
} 
examined above, only aircraft industry has presented a weak performance. The increase of our measure of domestic value added in relative terms to exports indicates that the share of components manufactured in China to the exports value is higher than it was some twenty years ago and that reflects Chinaís augmented capacity to participate in the value chain.

This astonishing performance reflects, of course, the process of fragmentation of production and the creation of Global Production Networks. But, as stressed by most authors, this could not be achieved without a great effort on innovation by China, making their firms capable to adopt and adjust foreign knowledge in order to climb up the technological ladder. And it is also the result of many years of investments in education on every level, from fundamental to superior degrees. A well educated and trained labor force is crucial for a rapid productivity increase like this one.

\section{CONCLUDING REMARKS}

The purpose of this paper was to present evidence about the profound changes that occurred in Chinaís high tech exports in the last two decades. More specifically, we wished to show, after presenting a general background on high tech goods bilateral flows, that China is transforming its role in the manufacturing process of this industry. Since the beginning of the last decade, China has been able to climb the technological ladder, not only increasing its exports of final goods but also its production of parts and components, as revealed by the huge increase in our gauge of domestic value added, the difference between exports of final goods and imports of parts and components. In office and data processing machines, for instance, the domestic value added as a $\%$ of total exports increased from - 25\% in 1992 to $85 \%$ in 2009 . At the same time, the same figure for professional, scientific and controlling instruments jumped from $21 \%$ to $75 \%$. The picture that emerges is that China, in many high tech sectors, like telecommunications and computer equipment, is no longer a mere final assembler but a producer of core technology embedded in vital parts and components goods.

This performance resembles, in many ways, what happened to other industrialized Asian countries in the recent past, like Japan, Korea or Taiwan. But what is striking here is the speed at what it is happening and its amount. As was shown, in many industries as important as computer and telecommunication, the share of Chinese exports is rapidly increasing and is already very substantial.

The analysis of the reasons behind this process is not the subject of this paper. Many factors may be presented, like the low cost of labor, the impact of domestic market scale on the production cost and the undervalued exchange rate. But certainly none of these could have had any big impact if the indigenous efforts in innovation and education 
were not made long before that. No country can be as competitive as China in goods as knowledge intensive as motherboards, chips, flat TVs components, etc. without a very high skilled labor force and a very integrated and technologically advanced manufacturing industry. This is even more remarkable when we remember that, in contemporary GPNs, domestic firms can be also held responsible not only for mass production but also for development process, like prototype building and pilot production. And for this to happen, there must be a lot of spillovers from one sector to the other and from one firm to the other.

\section{REFERENCES}

BONHAM, C.; GANGNES, B.; VAN ASSCHE, A. Fragmentation and East Asia’s information technology trade. Applied Economics, v. 39, p. 215-28, 2007.

DEDRICK, J.; KRAEMER, K.; LINDEN, G.; BROWN, C.; MURTHA, T. Organizing global knowledge networks in the electronics industry. PCIC/IC Irvine, June, 2007.

DUNNING, J. Location and the multinational enterprise: a neglected factor? Journal of International Business Studies, v. 29, n. 1, 1998.

DUNNING, J. Multinational enterprise and the global economy. Wokinghan: Addison-Wesley, 1993.

ERNST, D. The new mobility of knowledge: digital information systems and global flagship networks. In: LATHAM, R.; SASSEM, S. IT and new architectures in the global realm. Princeton and Oxford: Princeton University Press, 2005(a).

ERNST, D. Pathways to innovation in Asia's leading electronics-exporting countries a framework for exploring drivers and policy implications. International journal of technology management, v. 29, n. 1/2, 2005(b).

ERNST, D.; KIM, L. Global production networks, knowledge diffusion and local capability formation. A conceptual framework. East-West Center Working Papers, n. 19, Honolulu, USA, May, 2001.

GEREFFI, G. The organization of buyer-driven global commodity chains: how US retailers shape overseas production networks. In: GEREFFI, G.; KORZENIEWICZ, M. (Eds.) Commodity chains and global capitalism. Wesport - Connecticut / USA: Praeger, 1994, p. 95-122.

GEREFFI, G. International trade and industrial upgrading in the apparel commodity chain. Journal of international economics, v. 48, p. 37-70, 1999.

GEREFFI, G.; HUMPHREY, J.; STURGEON, T. The governance of global value chains. Review of international political economy, v. 12, n. 1, February, p. 78-104, 2005.

GRUBEL, H.; LLOYD, P. J. Intra-industry trade. London: Macmillan, 1975.

HELLEINER, G. K. Intra-firm trade and the developing countries. London: Macmillan, 1981. 
HELPMAN, E. International trade in the presence of product differentiation, economies of scale and monopolistic competition: a Chamberlin-Hecksher-Ohlin approach. Journal of international economics, v. 11, p. 305-340, 1981.

HOBDAY, M. East Asian latecomer firms: learning the technology of electronics. World Development, v. 23, n. 7, p. 1171-1193, 1995.

HOBDAY, M. East versus Southeast Asian innovation systems: comparing OEM and TNC-led growth in electronics. In: KIM, L.; NELSON, R. Technology, learning and innovation. Cambridge, UK: Cambridge University Press, 2000.

JONES, R.; KIERZKOWSKI, H.; LURONG, C. What does the evidence tell us about fragmentation and outsourcing. HEI Working Paper, Graduate Institute of International Studies/ Geneva, n. 9, 2004.

JONES, R.; KIERZKOWSKI, H. International trade and agglomeration: an alternative framework. HEI working paper, Graduate Institute of International Studies/Geneva, n. 10, 2004(a).

JONES, R.; KIERZKOWSKI, H. International fragmentation and the new economic geography. HEI working paper, Graduate Institute of International Studies/Geneva, n. 11, 2004(b).

KRUGMAN, P.- Increasing returns, monopolistic competition and international trade, Journal of International Economics, v. 9, p. 469-479, 1979.

KRUGMAN, P.- Scale economies, product differentiation and the pattern of trade. American Economic Review, v. 70, p. 950-959, 1980.

SRHOLEC, M. High tech exports from developing countries: a symptom of technology spurts or statistical illusion? Review of World Economics, v. 143, n. 2, p. 227-255, 2007.

UNCTAD. Trade and development report. New York and Geneva: United Nations, 2002.

WORLD TRADE ORGANIZATION (WTO); INSTITUTE OF DEVELOPING ECONOMIES (IDE-JETRO). Trade patterns and global value chains in East Asia. Geneva: WTO, 2011.

WORLD BANK. World Integrated Trade Solution. WITS. World Bank, 2010. Available at: <http:// wits.worldbank.org/WITS/>. Accessed on 2010. 


\section{ANNEX A}

\section{STANDARD INTERNATIONAL TRADE CLASSIFICATION, REVISION 3}

\section{GOODS CLASSIFIED AS HIGH TECH}

751 Office machines

752 Automatic data-processing machines and units thereof; magnetic or optical readers, machines for transcribing data onto data media in coded form and machines for processing such data, n.e.s.

759 Parts and accessories (other than covers, carrying cases and the like) suitable for use solely or principally with machines falling within groups 751 and 752

761 Television receivers (including video monitors and video projectors), whether or not incorporating radio-broadcast receivers or sound - or video-recording or reproducing apparatus

762 Radio-broadcast receivers, whether or not incorporating sound-recording or reproducing apparatus or a clock

763 Sound recorders or reproducers; television image and sound recorders or reproducers; prepared unrecorded media

764 Telecommunications equipment, n.e.s., and parts, n.e.s., and accessories of apparatus falling within division 76

776 Thermionic, cold cathode or photo-cathode valves and tubes (e.g., vacuum or vapour or gas-filled valves and tubes, mercury arc rectifying valves and tubes, cathode-ray tubes, television camera tubes); diodes, transistors and similar semiconductor devices;

792 Aircraft and associated equipment; spacecraft (including satellites) and spacecraft launch vehicles; parts thereof

871 Optical instruments and apparatus, n.e.s.

872 Instruments and appliances, n.e.s., for medical, surgical, dental or veterinary purposes

873 Meters and counters, n.e.s.

874 Measuring, checking, analyzing and controlling instruments and apparatus, n.e.s. 
881 Photographic apparatus and equipment, n.e.s.

882 Photographic and cinematographic supplies

883 Cinematographic film, exposed and developed, whether or not incorporating soundtrack or consisting only of soundtrack

884 Optical goods, n.e.s.

885 Watches and clocks 